\title{
PEMODELAN HIDROLOGI DENGAN MENGGUNAKAN WMS (WATERSHED MODELING SYSTEM), DAERAH KAJIAN DI DAS CILIWUNG HULU
}

\author{
(Penggunaan WMS untuk Ekstraksi Parameter DAS, Estimasi \\ Debit Puncak dan Hidrograf Aliran dengan Menggunakan \\ Metode Rasional)
}

\author{
Destianingrum Ratna P. ${ }^{1}$, M. Bayu Rizky Prayoga ${ }^{2}$, Ardila Yananto ${ }^{3}$
}

\begin{abstract}
Intisari
Permasalahan sumberdaya air dari hari ke hari semakin memburuk, baik kualitas maupun kuantitas air. DAS sebagai wadah dari berbagai komponen biosfer yang saling berinteraksi memegang peranan yang penting dalam siklus hidrologi dan fungsi penyediaan air. Berbagai macam model hidrologi telah dikembangkan, Model-model tersebut bisa digunakan untuk memecahkan permasalahan sumberdaya air tersebut. Salah satu model yang bisa digunakan adalah model rasional yang terdapat dalam Waterhsed Modeling System (WMS). Tujuan dari penelitian ini adalah untuk melakukan ekstraksi karakteristik DAS dan mengestimasi nilai debit puncak DAS Ciliwung Hulu berdasarkan nilai curah hujan beberapa kala ulang dengan menggunakan Watershed Modelling System.

Dari hasil penelitian didapatkan bahwa karakteristik DAS yang dapat diekstraksi dengan menggunakan WMS adalah luas DAS, panjang sungai utama, kemiringan DAS, dan kemiringan aliran sungai. Nilai koefisien aliran permukaan DAS Ciliwung Hulu adalah sebesar 0,72. Nilai intensitas hujan untuk kala ulang 2 tahun sebesar $117 \mathrm{~mm} / \mathrm{jam}$, kala ulang 5 tahun sebesar $135 \mathrm{~mm} / \mathrm{jam}$, kala ulang 10 tahun sebesar $143 \mathrm{~mm} / \mathrm{jam}$, kala ulang 25 tahun sebesar $152 \mathrm{~mm} / \mathrm{jam}$, kala ulang 50 tahun sebesar $157 \mathrm{~mm} / \mathrm{jam}$, dan kala ulang 100 tahun sebesar $162 \mathrm{~mm} / \mathrm{jam}$. Untuk nilai estimasi debit puncak di DAS Ciliwung Hulu, untuk kala ulang 2 tahun sebesar 735, $588 \mathrm{~m}^{3} /$ detik, untuk kala ulang 5 tahun sebesar $852,713 \mathrm{~m}^{3} /$ detik, untuk kala ulang 10 tahun sebesar $904,363 \mathrm{~m}^{3} /$ detik, untuk kala ulang 25 tahun sebesar 959,448 $\mathrm{m}^{3} /$ detik, untuk kala ulang 50 tahun sebesar 992,448 $\mathrm{m}^{3} /$ detik dan untuk kala ulang 100 tahun sebesar $1.023,313 \mathrm{~m}^{3} /$ detik.
\end{abstract}

Kata kunci: Watershed Modeling System, Daerah Aliran Sungai, Metode Rasional, Debit

\begin{abstract}
Water resources problems are getting worse from by the day, both the quality and quantity of water. Watershed as a container of various components of the interacting biosphere is playing an important role in the hydrological cycle and water supply functions. Various kinds of hydrological models have been developed. The models can be used to help solving the water resources problems. One of models that can be used are contained in Watershed Modeling System (WMS) is Rational Method. The purpose of this study was to perform the extraction of watershed characteristics and estimate the peak discharge in Ciliwung Hulu Watershed based on the value of rainfall in some return period by using the Watershed Modeling System.

The results of study show that the characteristics of the watershed that can be extracted by using WMS are watershed area, main stream length, the slope of the watershed, and the slope of the river. Runoff coefficient value of Ciliwung Hulu Watershed is 0,72. Rainfall intensity value for 2-year return period is $117 \mathrm{~mm} / \mathrm{h}$, when the 5 -year return period is $135 \mathrm{~mm} / \mathrm{h}$, when the 10-year return period is $143 \mathrm{~mm} / \mathrm{h}$, when the 25-year return period is $152 \mathrm{~mm} / \mathrm{h}$, when the 50-year return periods $157 \mathrm{~mm} / \mathrm{h}$, and when 100-year return period is $162 \mathrm{~mm} /$ hour. For the estimated value of the peak discharge in Ciliwung Hulu watershed for 2-year return period amounted to $735,588 \mathrm{~m}^{3} / \mathrm{sec}$, for 5-year return
\end{abstract}


period amounted to $852,713 \mathrm{~m}^{3} / \mathrm{sec}$, for a 10 -year return period amounted to 904,363 $\mathrm{m}^{3} / \mathrm{sec}$, for a 25 year return period amounted to $959,448 \mathrm{~m}^{3} / \mathrm{sec}$, for 50 -year return period amounted to $992,448 \mathrm{~m}^{3} / \mathrm{sec}$ and for 100 years return period amounted to 1023,313 $\mathrm{m}^{3} / \mathrm{sec}$.

Keywords: Watershed Modeling System, Watershed, Rational Method, Discharge

\section{PENDAHULUAN}

Indonesia merupakan salah satu negara yang tak lebas dari berbagi bencana, tak terkecuali bencana banjir yang terjadi hampir setiap tahunnya terutama di kota-kota besar di Indonesia. Berdasarkan kondisi morfologis, banjir bisa disebabkan karena adanya relief bentang alam Indonesia yang sangat bervariasi. Daerah rawan banjir tersebut diperburuk dengan adanya perubahan tata-guna lahan yang tidak memperhatikan daerah resapan air, bahkan saat ini pemanfaatan hutan yang bukan hutan produksi merupakan hal sering dijumpai.

Selain itu, perubahan tata-guna lahan yang kemudian berakibat menimbulkan bencana banjir, dapat dibuktikan antara lain di daerah perkotaan sepanjang pantai terutama yang dialiri dan sebagai outlet sungai. Penebangan hutan secara tidak terkontrol juga menyebabkan peningkatan koefisien aliran permukaan (run off) yang besar, sehingga dapat menimbukan banjir bandang dan kerusakan lingkungan di daerah satuan wilayah tertentu.

Berdasarkan data kejadian bencana, bencana hidrometeorologi menempati urutan terbesar $(53,3 \%)$ dari total kejadian bencana yang pernah terjadi di Indonesia. Dari total bencana hidrometeorologi tersebut, 34,1\%-nya merupakan banjir. Atas dasar kenyataan tersebut maka perlu dilakukan suatu analisis baik untuk memperoleh aspek-aspek morfologi DAS, koefisien aliran sungai, hidrograf aliran sungai, debit puncak.

Berkaitan dengan hal diatas, pengembangan metode analisis data DAS untuk ekstraksi informasi karakteristik DAS, hidrograf aliran hingga daerah limpasan aliran sungai sangatlah diperlukan terutama terkait dengan penanganan bencana hidrometeorologi, rencana pembangunan infrastruktur manajemen air, dan tata guna lahan. Untuk menunjang hal tersebut program WMS (Watershed Modeling System) bisa sangat diandalkan terutama terkait dengan pemodelan hidrologi.

Tujuan dari penelitian ini antara lain untuk mengetahui ; 1) ektraksi morfometri DAS, 2) nilai koefisien aliran DAS Ciliwung Hulu, 3) nilai Intensitas hujan di DAS Ciliwung Hulu dalam kala ulang tertentu berdasarkan data curah hujan historis, dan 4) estimasi debit puncak dan hidrograf aliran DAS Ciliwung Hulu dengan menggunakan Model Rasional.

\section{DASAR TEORI}

\subsection{Watershed Modelling System}

Model DAS adalah representasi matematis dari proses DAS dan terpengaruh sosio ekonomi dan lingkungan sistem. Ada banyak model DAS yang memiliki berbagai tingkat kecanggihan dan menyediakan beragam jenis informasi, tetapi semua model DAS mempunyai satu kesamaan karakteristik, yaitu mereka semua penyederhanaan proses DAS yang sebenarnya (Mirchi, 2009).

\section{Watershed Modeling System}

(WMS) merupakan sebuah aplikasi komputer berbasis data grid dimana didalamnya terdapat aplikasi Gridded Surface Subsurface Hydrologic Analysis (GSSHA). Model DAS dapat diklasifikasikan berdasarkan skala spasial dan temporal, metode yang diadopsi untuk memecahkan perhitungan dan pengertian mengenai proses hidrologi suatu Daerah Aliran Sungai (DAS) (Melone et. Al, 2005 dalam Daniel dkk, 2010).

\subsection{Koefisien Aliran DAS}

Pengaruh tata guna lahan pada aliran permukaan dinyatakan dalam koefisien aliran permukaan DAS (C). Koefisien aliran permukaan DAS adalah nlai yang menunjukkan perbandingan antara bersarnya aliran dengan besarnya curah hujan (Suripin, 2004). Nilai koefisien aliran ini merupakan salah satu indikator untuk menentukan kondisi fisik suatu DAS.

Nilai $C$ berkisar antara 0 sampai dengan 1 . Nilai $C=0$ menunjukkan bahwa semua air hujan terintersepsi dan terinfiltrasi ke dalam tanah, sebaliknya untuk nilai $C=1$ menunjukkan bahwa semua air hujan mengalir sebagai aliran permukaan. Pada DAS yang masih baik, harga $C$ mendekati ), semakin rusak suatu DAS, maka harga $C$ semakin mendekati satu (Suripin, 2004).

Menurut Chow, 1964 ; Gray, 1973 dalam Seyhan (1995) Nilai C dapat dilihat dalam Tabel 1.

\begin{tabular}{|c|c|}
\hline Tipe Kawasan DAS & $\begin{array}{c}\text { Koefisien } \\
\text { Limpasan }\end{array}$ \\
\hline
\end{tabular}




\begin{tabular}{|c|c|}
\hline Halaman rumput & \\
\hline tanah berpasir, datar (2\%) & $0,05-0,10$ \\
\hline tanah berpasir, rata-rata $(2-7 \%)$ & $0,10-0,15$ \\
\hline tanah berpasir, curam (7\%) & $0,15-0,20$ \\
\hline tanah berat, datar (2\%) & $0,13-0,17$ \\
\hline tanah berat, rata-rata $(2-7 \%)$ & $0,18-0,22$ \\
\hline tanah berat, curam (7\%) & $0,25-0,35$ \\
\hline Bisnis & \\
\hline Kawasan kota & $0,70-0,95$ \\
\hline Kawasan pinggiran & $0,50-0,70$ \\
\hline Kawasan permukiman & \\
\hline kawasan keluarga tunggal & $0,30-0,50$ \\
\hline multi satuan, terpisah & $0,40-0,60$ \\
\hline multi satuan, berdempetan & $0,60-0,75$ \\
\hline pinggiran kota & $0,25-0,40$ \\
\hline rumah susun & $0,50-0,70$ \\
\hline Perindustrian & \\
\hline kawasan yang ringan & $0,50-0,80$ \\
\hline kawasan yang berat & $0,60-0,90$ \\
\hline Taman-taman dan kuburan & $0,10-0,25$ \\
\hline Lapangan Bermain & $0,20-0,35$ \\
\hline Kawasan halaman Rel KA & $0,20-0,40$ \\
\hline Kawasan yang belum diperbaiki & $0,10-0,30$ \\
\hline Jalan-jalan & \\
\hline beraspal & $0,70-0,95$ \\
\hline beton & $0,8-0,95$ \\
\hline Jalan raya dan trotoar & $0,70-0,85$ \\
\hline Atap & $0,75-0,95$ \\
\hline
\end{tabular}

\begin{tabular}{|l|c|}
\hline \multicolumn{1}{|c|}{ Tipe Kawasan Pertanian } & Nilai $\mathrm{f}$ \\
\hline $\begin{array}{l}\text { Topografi } \\
\text { Lahan, datar, kemiringan rata-rata 1- } \\
\text { 3 kaki per mil } \\
\text { Lahan berombak, kemiringan rata- } \\
\text { rata 15- 20 kaki per mil }\end{array}$ & 0,30 \\
$\quad$ Lahan berbukit, kemiringan rata-rata \\
$\begin{array}{l}\text { 150 hingga 250 kaki per mil } \\
\text { Tanah }\end{array}$ & 0,20 \\
$\quad$ Liat kedap air yang rapat & 0,10 \\
$\quad$ Kombinasi medium dari liat dan & 0,10 \\
lempung & 0,20 \\
$\quad$ Lempung berpasir yang terbuka & 0,40 \\
Penutup Tanaman & \\
$\quad$ Lahan-lahan yang diusahakan & 0,10 \\
Lahan kayu & 0,20 \\
\hline
\end{tabular}

Untuk suatu DAS tertentu maka nilai C dalah :

\subsection{Perhitungan Intensitas Hujan DAS Ciliwung Hulu dengan Hujan Rancangan}

Hujan rancangan dapat ditentukan dengan metode metode statistika yakni analisis frekuensi data hujan (Widyasari, 2009). Analisis frekuensi data yang digunakan adalah data hujan dengan panjang data minimal 10 tahun. Maksud dari perhitungan hujan rancangan adalah untuk menghitung intensitas hujan kala ulang dengan menggunakan analisis frekuensi. Analisis frekuensi yang digunakan antara lain :
a. Distribusi Normal
b. Distribusi Log Normal
c. Distribusi Gumbel
d. Distribusi Log Pearson III

Uji chi kuadrat dan uji smirnov-kolmogorov juga dilakukan untuk memilih distribusi yang akan digunakan untuk perhitungan hujan rancangan. Untuk menghitung nilai intensitas hujan hasil dari analisis frekuensi pada masing-masing kala ulang, maka digunakan persamaan mononobe (Sosrodarsono, 1977). Rumus persamaan mononobe :

$$
I=\frac{R_{24}}{24}\left(\frac{24}{t}\right)^{2 / 3}
$$

Keterangan :

$$
\begin{array}{ll}
\mathrm{I} & =\text { Intensitas hujan }(\mathrm{mm} / \mathrm{jam}) \\
\mathrm{t} & =\text { waktu }(\mathrm{jam}) \\
\mathrm{R}_{24} & =\text { tinggi hujan rancangan dalam } 24 \\
\text { jam } &
\end{array}
$$

Konversi satuan intensitas hujan perlu dilakukan dalam model yang dijalankan WMS. Satuan intensitas hujan satuan dalam perhitungan masih dalam satuan $\mathrm{mm} / \mathrm{jam}$, oleh karena itu harus dikonservasi kedalam satuan inchi/jam.

\subsection{Estimasi Debit Puncak}

Watershed Modeling System mampu menghitung debit dengan data yang ada. Perhitungan Debit puncak dilakukan dengan menggunakan metode atau rumus rasional. Rumus ini banyak digunakan untuk sungai-sungai biasa dengan daerah aliran yang luas dan juga untuk perencanaan drainase DAS yang relatif sempit (Sosrodarsono, 1977). Rumus rasional tersebut dapat dijabarkan sebagai berikut :

$$
\begin{gathered}
\mathrm{Q}=\text { C. I. A cfs (cubic feet per second atau } \\
\text { secondfeet) }
\end{gathered}
$$

Atau apabila dalam satuan metrik maka rumus tersebut menjadi (Subarkah, 1980) :

$\mathrm{C}=\mathrm{f}_{\text {topografi }}+\mathrm{f}_{\text {tanah }}+\mathrm{f}_{\text {penutup tanaman }}$ 


$$
Q=0,278 \text { C. I. A m³ } / \text { detik }
$$

Keterangan :

$$
\begin{array}{ll}
\mathrm{Q} & =\text { Debit } \\
\mathrm{I} & =\text { Intensitas hujan } \\
\mathrm{A} & =\text { Luas DAS }
\end{array}
$$

\section{METODE PENELITIAN}

Tulisan ini menyampaikan konsep pemodelan hidrologi dengan menggunakan Watershed Modeling System (WMS). Dalam WMS terdapat beberapa modul atau metode yang bisa dipilih untuk analisis hidrologi maupun pemodelan hidrologi. Model yang digunakan dalam analisis pemodelan hidrologi DAS Ciliwung Hulu ini menggunakan model rasional.

Data yang digunakan sebagai input model hidrologi ini antara lain :

a. Data DEM.

Data DEM dapat diperoleh dari citra satelit ataupun dari hasil pengolahan Peta kontur. Semakin besar resolusi data DEM yang digunakan maka akan semakin baik.

b. Data hujan.

Data hujan yang digunakan adalah data hujan harian maksimum. Data hujan tersebut sebaiknya mempunyai series waktu yang panjang (minimal 10 tahun). Data hujan yang digunakan dalam penelitian ini adalah data Hujan dari Stasiun Bendung Katulampa dari tahun 1991-2005 (15 tahun).

c. Citra lkonos tahun 2013.

d. Peta hidrologi tanah.

e. Peta administrasi wilayah DAS Ciliwung Hulu.

Sebagai input utama dalam pemodelan ini adalah data DEM. Data DEM tersebut diolah dengan menggunakan WMS untuk menentukan morfometri DAS dan komponen DAS lain yang digunakan dalam komputasi model ini. Dengan menjalankan perintah (command) tertentu dalam WMS maka didapatkan morfometri DAS. Perhitungan nilai koefisien aliran dilakukan dengan menghitung masing-masing nilai koefisien aliran dari penggunaan lahan yang ada.

Perhitungan hujan rancangan dilakukan untuk mendapatkan nilai intensitas hujan. Analisis frekuensi digunakan dalam perhitungan hujan rancangan. Analisis frekuensi yang digunakan antara lain:
a. Distribusi normal
b. Distribusi log normal
c. Distribusi log pearson III, dan
d. Distribusi gumbel.

Pada masing - masing analisis distribusi, hasilnya dilakukan uji chi kuadrat untuk mengetahui analisis distribusi mana yang dianggap paling mewakili rangkaian data untuk diolah lebih lanjut. Setelah diuji menggunakan chi kuadrat, maka rangkaian data diuji kembali dengan menggunakan uji Smirnov - Kolmogorov. Tujuannya untuk memperkuat analisis dari distribusi statistik yang digunakan.

Setelah dilakukan pengujian Chi Kuadrat dan Smirnov - Kolmogorov, maka didapatkan hasil bahwa rangkaian data memenuhi persyaratan untuk dilakukan analisis lebih lanjut dalam menyusun perhitungan hujan rancangan. Nilai hujan rancangan yang digunakan adalah hasil perhitungan dari Distribusi Log Pearson III.

Perhitungan nilai debit dilakukan dengan menggunakan model rasional. Parameterparameter yang dibutuhkan untuk perhitungan model ini di masukkan secara manual kemudian dijalankan dengan menggunakan WMS model rasional. Model rasional ini dapat menghitung nilai debit pada setiap kala ulang. Kala ulang yang dihitung adalah kala ulang 2 tahun, 5 tahun, 10 tahun, 25 tahun, 50 tahun dan 100 tahun.

\section{HASIL DAN PEMBAHASAN}

Hasil dari kegiatan ini terbagi menjadi beberapa bagian utama, yaitu ekstraksi informasi morfometri DAS Ciliwung Hulu, perhitungan nilai koefisien aliran permukaan DAS Ciliwung Hulu, perhitungan hujan rancangan, penggunaan Model Rasional untuk estimasi nilai debit puncak berdasarkan nilai intensitas hujan pada kala ulang tertentu untuk memperoleh perkiraan hidrograf aliran di DAS Ciliwung Hulu.

Secara keseluruhan luas total DAS Ciliwung Hulu berkisar $144,93 \mathrm{Km}^{2}$. Dimana Jenis penggunaan lahan hutan lebat masih mendominasi, yaitu seluas $50,1 \mathrm{~km}^{2}$ atau berkisar $34,57 \%$ dari keseluruhan luas DAS. Jenis Penggunaan lahan berupa perkebunan juga relatif cukup luas, yaitu berkirar $19,19 \mathrm{~km}^{2}$. Penggunaan lahan berupa permukiman di DAS Ciliwung hulu kurang lebih seluas $19,03 \mathrm{~km}^{2}$ atau berkisar $13,13 \%$ dari luas keseluruhan DAS Ciliwung Hulu.

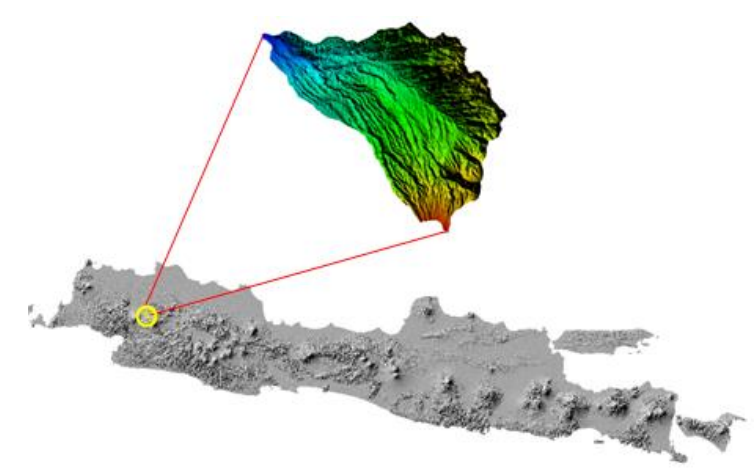

Gambar 1. Topografi Daerah Aliran Sungai Ciliwung Hulu dari citra SRTM 
Tabel 2. Jenis Penggunaan Lahan DAS Ciliwung Hulu

\begin{tabular}{|c|l|r|r|}
\hline No & \multicolumn{1}{|c|}{ Penggunaan Lahan } & Luas $\left(\mathbf{K m}^{2} \mathbf{)}\right.$ & \multicolumn{1}{c|}{$\begin{array}{c}\text { Prosentase } \\
(\%)\end{array}$} \\
\hline 1 & Daerah Industri & 0.21 & 0.14 \\
\hline 2 & Danau/situ/telaga & 0.02 & 0.01 \\
\hline 3 & Hutan Belukar & 0.56 & 0.39 \\
\hline 4 & Hutan lebat & 50.10 & 34.57 \\
\hline 5 & Hutan Sejenis & 0.04 & 0.03 \\
\hline 6 & Jalan & 0.11 & 0.08 \\
\hline 7 & Kebun Campuran & 13.34 & 9.21 \\
\hline 8 & Kebun Sayuran & 1.33 & 0.92 \\
\hline 9 & Kolam air tawar & 0.06 & 0.04 \\
\hline 10 & Padang rumput & 0.01 & 0.00 \\
\hline 11 & Padang rumput penggembalaan & 4.35 & 3.00 \\
\hline 12 & Padang terbuka & 0.02 & 0.01 \\
\hline 13 & Perdagangan & 0.07 & 0.05 \\
\hline 14 & Perkebunan & 27.81 & 19.19 \\
\hline 15 & Permukiman & 3.34 & 2.30 \\
\hline 16 & Permukiman Padat & 13.54 & 9.34 \\
\hline 17 & Permukiman Petani & 2.15 & 1.49 \\
\hline 18 & Peternakan & 0.14 & 0.09 \\
\hline 19 & Sawah & 17.81 & 12.29 \\
\hline 20 & Sungai & 0.53 & 0.36 \\
\hline 21 & Taman & 0.42 & 0.29 \\
\hline 22 & Tanaman Semusim & 8.98 & 6.20 \\
\hline \multicolumn{2}{|l|}{ Luas DAS Ciliwung Hulu } & 144.93 & 100 \\
\hline
\end{tabular}

Sumber : Interpretasi citra Ikonos dan Quickbird Tahun 2013

Dengan aturan minimal luasan jenis penggunaan lahan hutan $30 \%$ dari total keseluruhan suatu DAS, maka sebenarnya DAS ciliwung Hulu masih memenuhi persyaratan tersebut, akan tetapi jika dibandingkan dengan luas DAS Ciliwung secara keseluruhan baik hulu maupun hilir, luas hutan tersebut hanya berkisar $8,95 \%$ atau kurang dari sepertiga syarat minimum luas hutan dalam sistem DAS. Oleh karena itu sangat wajar jika terjadi hujan yang lebat, akan sering mengakibatkan banjir di daerah DKI Jakarta dan sekitarnya, dikarenakan daerah resapan air di sistem DAS yang sudah sangat berkurang.

\subsection{Ekstraksi Morfometri DAS Ciliwung Hulu}

Ekstraksi informasi morfometri DAS dilakukan dengan data dasar berupa citra satelit yang memuat informasi topografi. Citra satelit yang digunakan adalah produk dari SRTM. Data dasar berupa file Digital Elevation Model dengan ekstensi .dem.

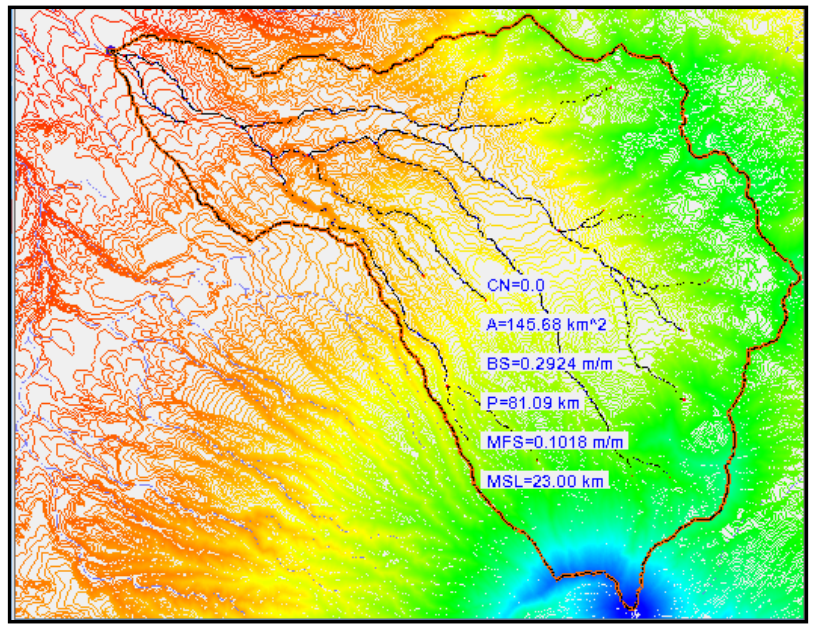

Gambar 2. Morfometri DAS Ciliwung Hulu.

Dari hasil komputasi batas DAS yang dilakukan, dapat diketahui nilai dari masingmasing variabel morfometri DAS. Luas DAS Ciliwung Hulu adalah $144,93 \mathrm{~km}^{2}$ dengan keliling DAS sekitar $75 \mathrm{~km}^{2}$. Panjang maksimal aliran sungai di DAS Ciliwung Hulu kurang lebih $22 \mathrm{~km}$. Kemiringan DAS rata-rata berkisar $0,25 \mathrm{~m} / \mathrm{m}$, sedangkan kemiringan aliran maksimal di DAS Ciliwung Hulu adalah $0.05 \mathrm{~m} / \mathrm{m}$.

\subsection{Nilai Koefisien Aliran Permukaan Ciliwung Hulu}

Penggunaan lahan merupakan salah satu faktor yang mempengaruhi kondisi aliran permukaan suatu DAS. Penggunaan lahan berperan dalam menentukan besarnya nilai koefisien aliran dalam suatu DAS. Semakin luas luasan penggunaan lahan yang terpengaruh oleh manusia (misalnya pemukiman, bangunan dan yang lainnya) maka dapat menyumbang besarnya koefisen aliran yang terjadi.

Hasil pengolahan data dan interpretasi citra di dapatkan bahwa nilai koefisien aliran untuk DAS Ciliwung Hulu adalah sebesar 0,72. Angka tersebut mengandung makna bahwa sekitar $72 \%$ dari hujan total yang terjadi di Wilayah DAS Ciliwung Hulu akan menjadi aliran permukaan (limpasan/run off). Besarnya koefisien aliran tersebut akan berpengaruh terhadap besarnya debit sungai yang nantinya akan berkontribusi pada kondisi banjir di Jakarta.

\subsection{Hujan Rancangan DAS Ciliwung Hulu}

Sebelum bisa mendapatkan prediksi debit pada beberapa periode ulang di DAS Ciliwung hulu, perlu dilakukan perhitungan hujan rancangan di daerah tersebut. Nilai hujan rancangan yang diperoleh dari hasil perhitungan yang tertuang dalam Tabel 3.

Tabel 3. Nilai hujan rancangan $(\mathrm{Xt})$ hasil perhitungan Distribusi Log Pearson III.

\begin{tabular}{cc}
\hline Kala ulang (tahun) & Nilai $\mathbf{X t}$ (mm/jam) \\
\hline $\mathbf{2}$ & 117 \\
$\mathbf{5}$ & 135 \\
$\mathbf{1 0}$ & 143 \\
$\mathbf{2 5}$ & 152 \\
$\mathbf{5 0}$ & 157 \\
$\mathbf{1 0 0}$ & 162 \\
\hline
\end{tabular}

Sumber: hasil analisis data 
Setelah nilai hujan rancangan $(\mathrm{Xt})$ pada distribusi yang telah dipilih didapatkan, maka dapat dihitung nilai hujan rancangan setiap kala ulangnya. Hasil perhitungan hujan rancangan (inchi/jam) setiap kala ulang tersaji dalam tabel 4.

Tabel 4. Hasil Perhitungan Hujan Rancangan Setiap Kala Ulang

\begin{tabular}{|c|c|c|c|c|c|c|}
\hline \multirow{2}{*}{$\begin{array}{c}\text { Waktu } \\
\text { (menit) }\end{array}$} & \multicolumn{5}{|c|}{ Intensitas hujan rancangan (inchi/jam) } \\
\cline { 2 - 7 } & $\mathbf{2}$ & $\mathbf{5}$ & $\mathbf{1 0}$ & $\mathbf{2 5}$ & $\mathbf{5 0}$ & $\mathbf{1 0 0}$ \\
tahun & tahun & tahun & tahun & tahun & tahun \\
\hline 5 & 8,37 & 9,65 & 10,23 & 10,87 & 11,23 & 11,58 \\
\hline 10 & 5,27 & 6,08 & 6,44 & 6,85 & 7,075 & 7,300 \\
\hline 15 & 4,02 & 4,64 & 4,91 & 5,22 & 5,39 & 5,57 \\
\hline 30 & 2,53 & 2,92 & 3,09 & 3,29 & 3,40 & 3,50 \\
\hline 60 & 1,59 & 1,84 & 1,95 & 2,07 & 2,14 & 2,21 \\
\hline
\end{tabular}

Sumber : Pengolahan Data

Hubungan antara intensitas hujan dengan waktu dapat digambarkan dalam sebuah grafik/kurva, yakni kurva IDF (Intencity Duration Frequency) atau kurva intensitas durasi frekuensi.

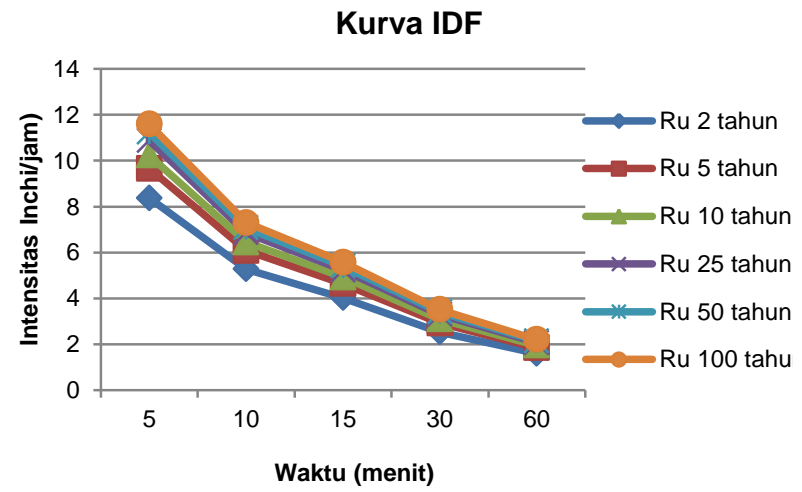

Gambar 3. Kurva IDF Stasiun Katulampa.

\subsection{Estimasi Debit Puncak dengan Metode Rasional}

Estimasi debit puncak dengan menggunakan Model Rasional dilakukan setelah mendapatkan nilai hujan rancangan tiap jam. Setelah nilai hujan rancangan tiap jam diperoleh maka tahapan selanjutnya adalah memasukkan masing - masing nilai hujan rancangan pada beberapa periode ulang tertentu.

Dalam kegiatan ini, digunakan hasil perhitungan hujan rancangan yang telah didapatkan. Hujan rancangan yang digunakan sebagai masukan data untuk melakukan estimasi debit puncak dengan metode rasional mendapatkan hasil estimasi seperti Tabel 5.
Tabel 5. Estimasi Debit Puncak dengan Metode Rasional

\begin{tabular}{|c|c|c|c|c|}
\hline $\begin{array}{c}\text { Kala Ulang } \\
\text { (tahun) }\end{array}$ & $\mathbf{C}$ & $\mathbf{I}(\mathbf{m m} / \mathbf{h r})$ & $\mathbf{A}(\mathbf{H a})$ & $\begin{array}{c}\mathbf{Q} \\
\left(\mathbf{m}^{3} / \mathbf{d e t i k}\right)\end{array}$ \\
\hline 2 & 0,72 & 25,378 & 14492,72 & 735,588 \\
\hline 5 & 0,72 & 29,419 & 14492,72 & 852,713 \\
\hline 10 & 0,72 & 31,201 & 14492,72 & 904,363 \\
\hline 25 & 0,72 & 33,096 & 14492,72 & 959,289 \\
\hline 50 & 0,72 & 34,240 & 14492,72 & 992,448 \\
\hline 100 & 0,72 & 35,304 & 14492,72 & 1023,313 \\
\hline
\end{tabular}

Sumber : Analisis Data

Nilai estimasi debit puncak seperti pada Tabel 4 menunjukkan bahwa debit puncak Ciliwung Hulu akan semakin meningkat pada beberapa kala ulang. Hal ini tentunya tak lepas dari besarnya hujan rancangan dan parameter penggunaan lahan yang sangat berpengaruh pada nilai koefisien aliran nantinya.

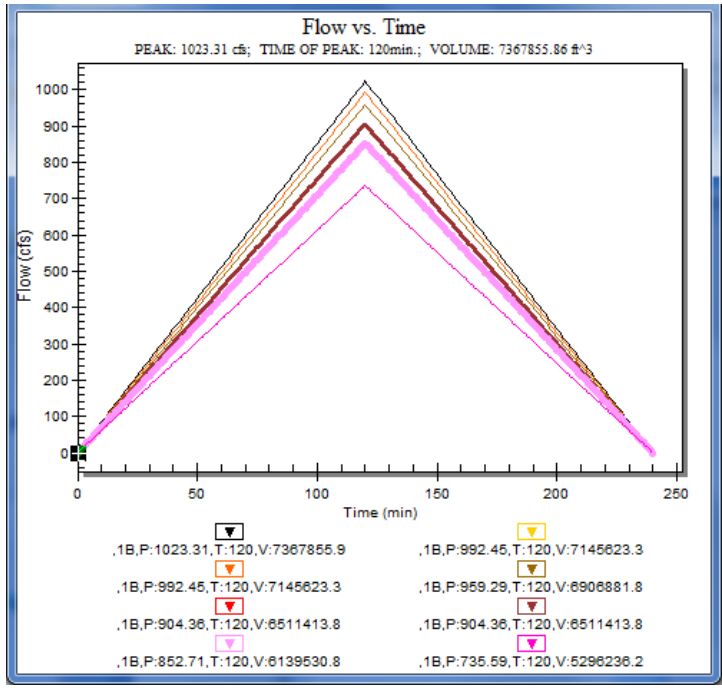

Gambar 4. Hidrograf aliran Ciliwung Hulu pada beberapa periode kala ulang $(2,5,10$, 25, 50, dan 100 tahun).

Gambar 4 menunjukkan hidrograf aliran di DAS Ciliwung Hulu. Dapat diamati bahwa waktu puncak aliran pada masing - masing kala ulang ada pada $T=120$ menit. Itu artinya, pada skenario hujan rancangan dan penggunaan lahan seperti yang dilakukan dalam penelitian ini, akan menghasilkan besar aliran puncak yang akan terjadi pada waktu 2 jam setelah mulai turun hujan. Beberapa periode kala ulang menunjukkan pola yang sama pada hasil hidrograf aliran dengan menggunakan metode rasional. 


\section{KESIMPULAN}

Pemodelan hidrologi di DAS Ciliwung Hulu dengan menggunakan WMS bisa digunakan sebagai salah satu prediksi nilai debit puncak di DAS tersebut. Berdasarkan hasil pengolahan dan analisis data yang telah dilakukan, didapatkan karakteristik fisik DAS Ciliwung Hulu yaitu, panjang maksimal aliran sungai di DAS Ciliwung Hulu adalah $22 \mathrm{~km}$. Kemiringan DAS rata-rata berkisar $0,25 \mathrm{~m} / \mathrm{m}$, sedangkan kemiringan aliran maksimal di DAS Ciliwung Hulu adalah $0,05 \mathrm{~m} / \mathrm{m}$. Nilai koefisien aliran permukaan di DAS Ciliwung Hulu sebesar 0,72 . Nilai koefisien tersebut mempunyai arti dari banyaknya hujan yang jatuh ke permukaan DAS Ciliwung Hulu, maka air sebanyak $72 \%$ dari total curah hujan yang turun akan menjadi limpasan di DAS Ciliwung Hulu. Didapatkan juga besarnya hujan rancangan dan estimasi debit puncak yang akan terjadi di DAS Ciliwung Hulu dengan parameter seperti pada penelitian ini. Besarnya nilai hujan rancangan dan estimasi debit puncak pada kala ulang 2, 5, 10, 25, 50 , dan 100 tahun nilainya menunjukkan kecenderungan yang meningkat.

\section{DAFTAR PUSTAKA}

Daniel, E. B., Camp, J. V., LeBoeuf, E. J., Penrod, J. R., Abkowitz, M. D., dan Dobbins, J. P. 2010. Watershed Modelling Using GIS Technology: A Critical Review. Journal of Spatial Hydrology Vol 10, No. 2, Fall 2010. Tennessee : Department of Civil Environmental Engineering.

Mirchi, A.,Watkins, D., Madani, K. 2009. Modeling For Watershed Planning, Management and Decision Making. Watershed : Management, Restoration and Environmental. P.1-25, Chapter 6. Nova Science Publishers, Inc.

Seyhan, E. 1995. Dasar-Dasar Hidrologi. Yogyakarta : Gadjah Mada University Press

Sosrodarsono, S., Takeda, K. 1977. Hidrologi Untuk Pengairan. Jakarta: Pradnya Paramita

Subarkah, I. 1980. Hidrologi untuk Perencanaan Bangunan Air. Bandung: Idea Dharma.

Suripin. 2004. Pelestarian Sumberdaya Tanah dan Air. Yogyakarta:Penerbit Andi.

Widyasari, . 2009. Kurva Intensitas Durasi Frekuensi (IDF) Persamaan Mononobe di Kabupaten Sleman. Janateknika Vo.11 No.2/Juli 2009. Halaman 85-94. 